\title{
Short Communication: Taxonomy and the first report for pollen and leaf surfaces anatomy of the genus Enkleia (Thymelaeaceae) in Thailand
}

\author{
PIYAPORN SAENSOUK ${ }^{1}$, SURAPON SAENSOUK ${ }^{2, \bullet}$ \\ ${ }^{1}$ Department of Biology, Faculty of Science, Mahasarakham University. Maha Sarakha 44150, Thailand \\ ${ }^{2}$ Walai Rukhavej Botanical Research Institute, Mahasarakham University, Kantarawichai District. Maha Sarakham, 44150, Thailand. \\ vemail: surapon.s@msu.ac.th
}

Manuscript received: 28 January 2021. Revision accepted: 17 February 2021.

\begin{abstract}
Saensouk P, Saensouk S. 2021. Short Communication: Taxonomy and the first report for pollen and leaf surfaces anatomy of the genus Enkleia (Thymelaeaceae) in Thailand. Biodiversitas 22: 1340-1344. Taxonomic of the genus Enkleia in Thailand are revised. Two species, Enkleia malaccensis Griff. and E. thorelii (Lecomte) Nevling, are reported. Enkleia siamensis (Kurz) Nevling and E. siamensis (Kurz) Nevling subsp. andamanica (Hutch. Ex C. E. Parkinson) Nevling are reduced to Enkleia malaccensis Griff.. Therefore, both species are recorded as synonym of E. malaccensis. E. thorelii is reported endemic to Thailand. Vernacular name, distribution data, ecological data, flowering period, fruiting period, conservation status, traditional use of this genus are provided. The pollen and leaf surfaces of the genus are examined and the first studied.
\end{abstract}

Keywords: Enkleia, leaf surfaces, pollen, taxonomic revision, Thymelaeaceae

\section{INTRODUCTION}

The genus Enkleia is in the family Thymelaeaceae order Malvales. Three species of Enkleia are accepted species names worldwide (The Plant list 2017). Previously study, Peterson (1997) studied five genera with five species four varieties of Thymelaeaceae in Thailand and found that the genus Enkleia is reported two species and two varieties, namely Enkleia siamensis var. siamensis, E. siamensis var. andamanica and $E$. thorelii. The scientific plant names of infraspecific rank for the genus Enkleia has changed. Therefore, this research will study taxonomic revision, pollen and leaf surface anatomy of the genus Enkleia in Thailand. The pollen and leaf surfaces by peeling method of this genus are never previously studied.

\section{MATERIALS AND METHODS}

\section{Taxonomic revision and traditional uses}

Literature reviews are checked. Herbarium materials are studied from aboard herbaria (BK, BKF, QBG). The Enkleia specimens are collected, pressed and fixed in $70 \%$ alcohol during field trips between January and December 2018-2020 from the field in Thailand. Voucher specimens were deposited in herbaria. All species are described. Diversity information, ecological information, distribution of floristic regions, ecology, phonological data, and valuable notes are reported .Uses data of the genus was obtained through interviewing local villagers. A preliminary conservation assessment was prepared based on the IUCN Red List categories (2020).

\section{Palynology}

Pollens of genus Enkleia were analyzed using an alcohol series (Kajornjit et al. 2018; Saensouk and Saensouk 2018), 70\%, 80\%, 95\%, and $100 \%$ respectively. The pollens were studied under light microscopy (LM) and scanning electron microscopy (SEM). Under the LM study, two-three drops of silicone oil were dropped onto the pollen grains. Then the pollen grains in the silicone oil were mounted on slides and sealed with paraffin. Under the SEM study, the pollens in absolute alcohol were transferred, mounted and affixed on aluminum stubs with double-sided cellophane tape. Samples were sputter-coated with a gold-palladium, examined and then photographs were taken with scanning electron microscope or SEM (Hitachi, TM- 4000plus) at Laboratory Equipment Center, Division of Research facilitation and dissemination, Mahasarakham University. The measurements were based on 20 pollens from each specimen.

\section{Anatomical studies: Peeling leaf surfaces}

Leaves of Enkleia were taken from spirit or fresh specimens. The specimens were analyzed follow Thammathaworn (1995), Prasawang and Srinual (2020), Rakarcha et al. (2018), and Saensouk et al. (2015). The specimens were investigated under light microscope. Photographs were taken using a Zeiss Axiostar plus light microscope at 100x magnification. 


\section{RESULTS AND DISCUSSION}

\section{Taxonomic revision of the genus Enkleia}

Taxonomic revision of the genus Enkleia is studied. The genus is belonging to subfamily Thymelaeoideae, tribe Daphneae, and Linostoma group. The genus is belonging to subfamily Thymelaeoideae, tribe Daphneae and Linostoma group which differs from previously studied (Peterson 1997). Two species are recorded in this study which is $E$. malaccensis Griff. and E. thorelii (Lecomte) Nevling but it disagrees with previously reported of Peterson (1997) as two species two subspecies. Therefore, a key to species of Enkleia based on the study of Peterson (1997) has been revised below.

A revised key to species of genus Enkleia in Thailand

1. Erect or straggling shrub 2-5 m high or woody climber; Inflorescence umbelliform............Enkleia malaccensis

1. Erect shrub $50-70 \mathrm{~cm}$ high with thick rootstock; Inflorescence paniculiform. Enkleia thorelii

Enkleia malaccensis Griff., Calcutta J. Nat. Hist. 4: 235. 1844. - Enkleia siamensis (Kurz) Nevling, J. Arnold Arbor. 42: 391. 1961; Rao \& Bhupal, Curr. Sci. 41: 884. 1972; Pham HÔ in Fl. C.L.V. 26: 56. 1992. - Enkleia siamensis (Kurz) Nevling ssp. siamensis. - Linostoma siamensis Kurz, J. As. Soc. Bengal 39: 82. 1870; Fl. Burm. 2: 335. 1877. - L. scandens (Endl.) Kurz var. cambodianum Lec., Not. Syst. 3: 127.1915. "cambodiana"; in Fl. C.L.V. 5: 175. 1915. - Enkleia siamensis (Kurz) Nevling ssp. andamanensis (Hutch. ex Parkins.) Nevling, J. Arnold Arbor. 42: 391. 1961. Linostoma andamanensis Hutch. ex Parkins., For. Fl. Andam. 229. 1923. "andamanica" - E. andamanensis (Hutch. ex Parkins.) Balakr., Bull. Bot. Surv. India 22: 176. 1980 (1982).

Erect or straggling shrub 2-5 m high or woody climber, young branches bark brown-reddish, glabrescent. Leaves opposite or sometimes alternate, ovate-elliptic, rarely orbicular, 3-6 x 5-10 cm, apex acute to obtuse, often minutely mucronate, base cuneate to obtuse, coriaceous, upper surface glabrous except hairy in midrib, lower surface densely pubescence, especially along midrib and lateral vein, $15-25$ lateral veins, petiole $6-8 \mathrm{~mm}$ long with glabrescent and pubescent. Inflorescence umbelliform, terminal, 3-15 flowered, peduncle $2-5 \mathrm{~cm}$ long, bract elliptic, obtuse at the apex and base, membranous, 1-1.5 x 2-5 cm, pubescent on both surface, bracteoles small filiform. Flowers greenish or yellow. Calyx tube 7-8 mm long, calyx lobes 5, 1.5-2 x 3-4 mm, pubescent on both surfaces. Corolla tube slender, ca $2.5 \mathrm{~mm}$ long, corolla lobe 5, oblong, ca $2.5 \mathrm{~mm}$ long. Stamens 10, filament 0.5-1.5 $\mathrm{mm}$, glabrous, anthers ca. $1 \mathrm{~mm}$ long, ovary superior, elliptic, 1-2 mm long, densely sericeous, 1 locule, 1 ovule, style short, stigma capitates. Fruits green, pubescent, 6-8 x 10-15 mm, acute apex, with 2 bracts, brownish, 2-4 cm long. Seeds ovate, 4-5 x 6-8 mm. (Figures 1.A-1.B)

Vernacular. - Po tao hai, Tao hai, Po taptao, Phaya mai phu, Phan chainai, Phan sanai (Thai name)
Distribution. - Southeast Asia - Myanmar, Thailand, Cambodia, Laos, Malaysia, Indonesia. In Thailand N, NE, E, SW, SE, PEN.

Ecology. - deciduous dipterocarp forest, Andaman Island, alt. 150-500 $\mathrm{m}$ above sea level, according to Peterson (1997).

Flowering period. - March

Fruiting period. - July

Traditional use. - The fiber from the barks can be used as a rope.

Specimens examined. - A.F.G. Kerr 20601 (BK!); A.F.G. Kerr 10620 (BK!); A.F.G. Kerr 19959 (BK!); BGO Staff s.n. (QBG!); Chamlong Phengkhlai 3791 (BKF!); J.F. Maxwell 74-89 (BK!); J.F. Maxwell 88-196 (BKF!); J.F. Maxwell 96-1268 (BKF!); M. Norsaengsri, W. Laongsri, P. Phaosrichai \& P. Tatiya 9108 (QBG!); Sabol 434 (BK!); Adisai 221 (BK!); Stuart Lindsay, Somran Suddee \& Suwat Suwannachat 3707 (BKF!); Phyawinit 1590 (BKF!); S. Phengnaren s.n. (BKF!); TS. 6655 (BKF!); T. Smitinand 8436 (BKF!); Somran Suddee, P. Trisarasri, M. Thanaros \& N. Riphet 3061 (BKF!).

Conservation status. - This species is here proposed as being not evaluated by IUCN criteria (2020). We suggest treating this species as list to concern (LC) based on the widely distributions of this species.

Note. - Enkleia siamensis (Kurz) Nevling, E. siamensis (Kurz) Nevling subsp. andamanica (Hutch. Ex C. E. Parkinson) Nevling are synonym of E. malaccensis Griff.

Enkleia thorelii (Lec.) Nevling, J. Arnold Arbor. 42: 391. 1961. - Linostoma thorelii Lec., Not. Syst. 3: 127. 1915; in Fl. Gén. L.-C. 5: 175. 1915.

Erect shrub $50-70 \mathrm{~cm}$ high with thick rootstock, branches bark greenish-reddish, pubescent to glabrescent. Leaves opposite to alternate, elliptic, 1.5-2 x 3-5 cm, apex obtuse, mucronate, base cuneate, coriaceous, upper surface glabrous or slightly hairy at the base, lower surface pubescence, especially along midrib and lateral vein, glabrescent, 15-25 pairs lateral veins, petiole 2-5 mm long with glabrescent and pubescent. Inflorescence paniculiform, terminal, 6-18 flowered, peduncle $2-5 \mathrm{~cm}$ long, bract below the middle of the peduncle, up to ca $20 \mathrm{x}$ $35 \mathrm{~cm}$, elliptic, yellowish to greenish, obtuse at the apex and base, membranous, pubescent on both surfaces. Flowers yellowish to white. Calyx tube 7-10 mm long, calyx lobes 5, 1.5-2 x 3-5 mm. Corolla tube slender, 3-6 $\mathrm{mm}$ long, corolla lobe 5, oblong, ca $2.5 \mathrm{~mm}$ long. Stamens 10 , filament up to $0.5 \mathrm{~mm}$, glabrous, anthers ca. $1.5 \mathrm{~mm}$ long, ovary superior, fusiform, 1-2 mm long, densely sericeous at top, 1 locule, 1 ovule, style ca. $1 \mathrm{~mm}$ long, stigma clavate. Fruits green when young, slightly pubescent at the top, 7-8 x 14-15 mm, acute apex, with 2 bracts, greenish, ca. $4 \mathrm{~cm}$ long. Seeds ovate, ca. 5 x $7 \mathrm{~mm}$. (Figures 1.C-1.E)

Vernacular. - Pra doo Kok (Thai name)

Distribution. - Endemic to Thailand in NORTHEASTERN (Maha Sarakham) and EASTERN (Nakhon Ratchasima, Ubon Ratchathani) 


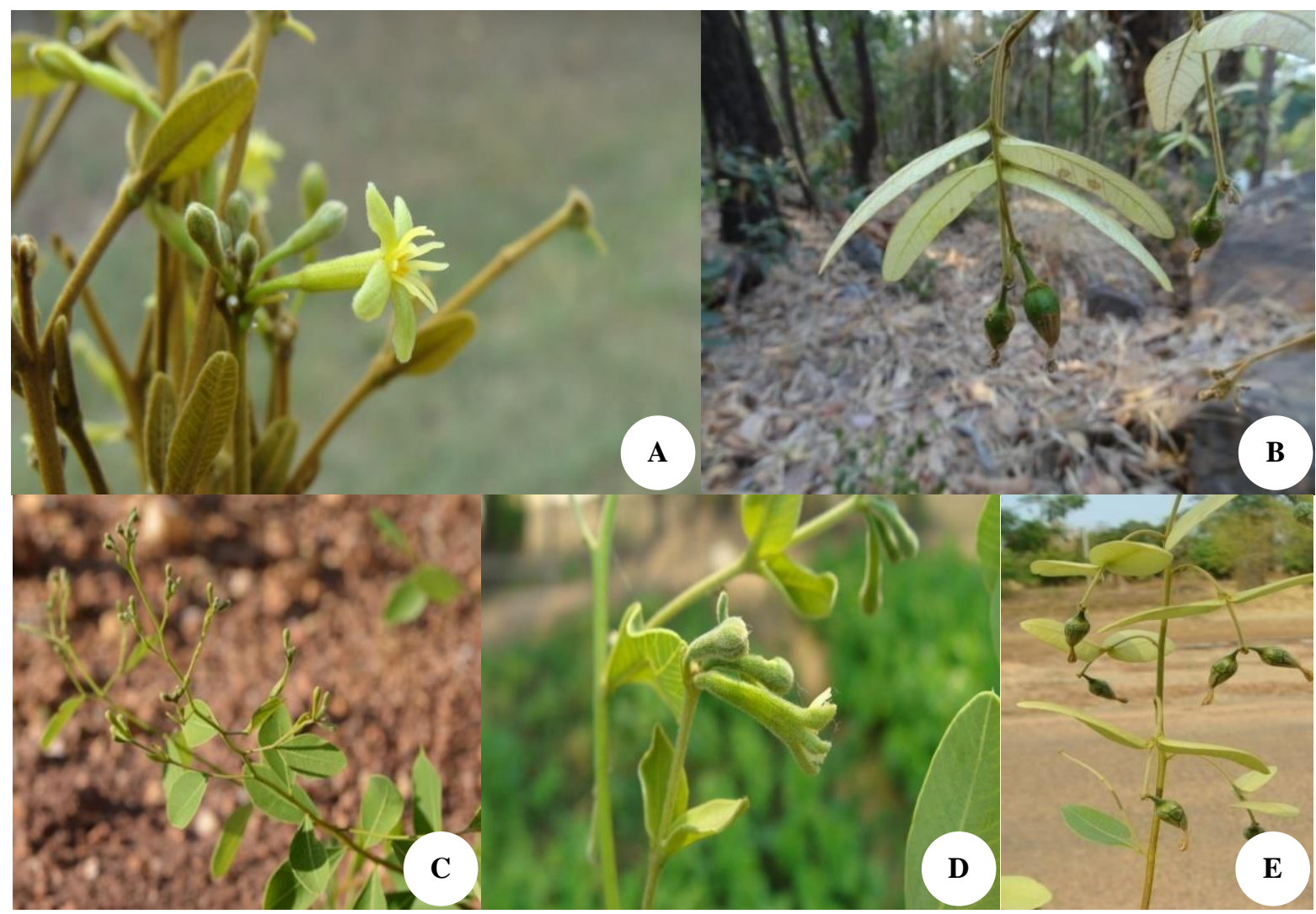

Figure 1. A-B. Enkleia malaccensis Griff.: A. Flowers, B. Fruits; C-E. Enkleia thorelii (Lec.) Nevling: C. Inflorescence and flowers, D. Flowers, E. Fruits

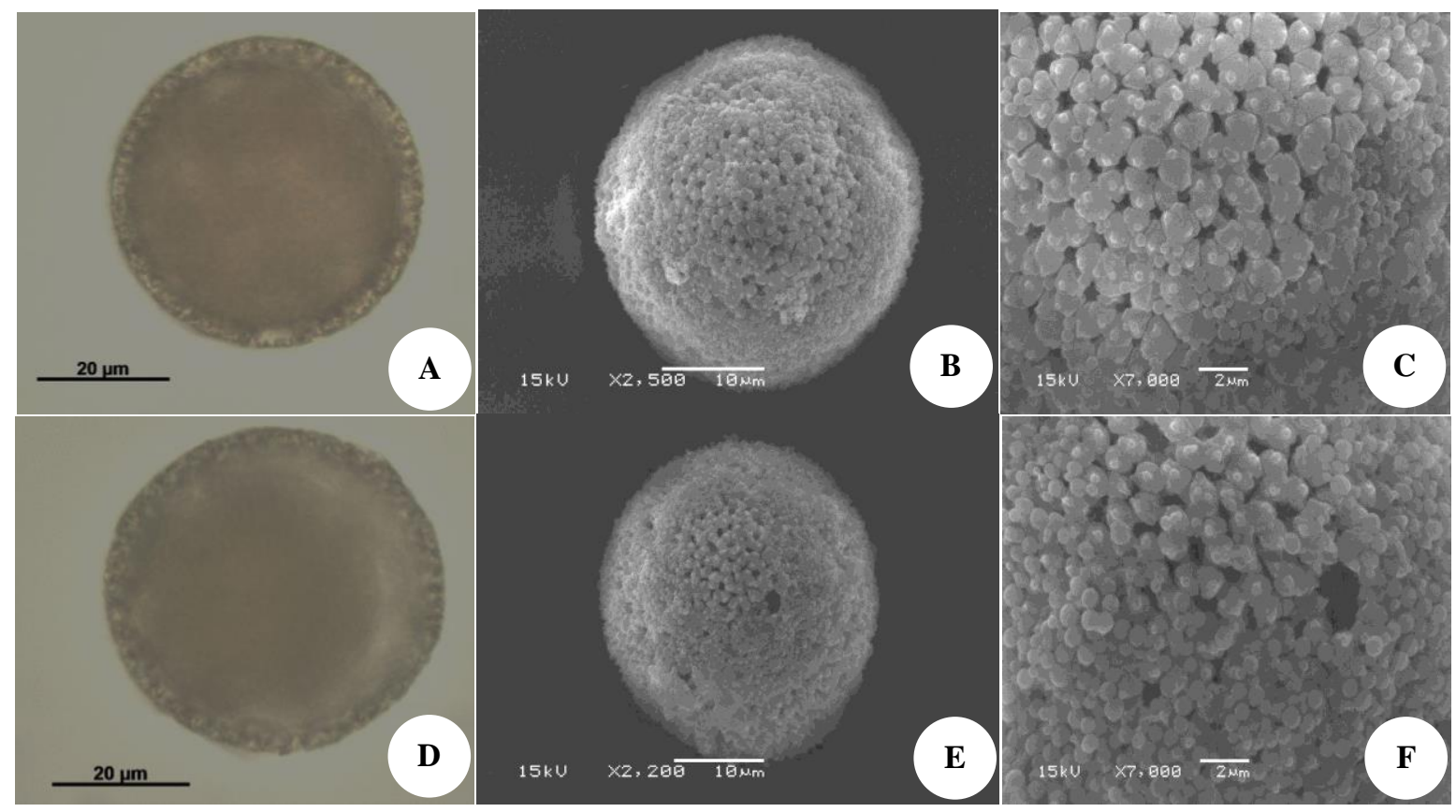

Figure 2. Pollen of Enkleia 2 species; A-C. Pollen of Enkleia malaccensis: A. Pollen under LM, B. Pollen under SEM, C. Exile sculpturing crotonoid pattern; D-F. Pollen of Enkleia thorelii: D. Pollen under LM, E. pollen under SEM, F. Exile sculpturing crotonoid pattern 


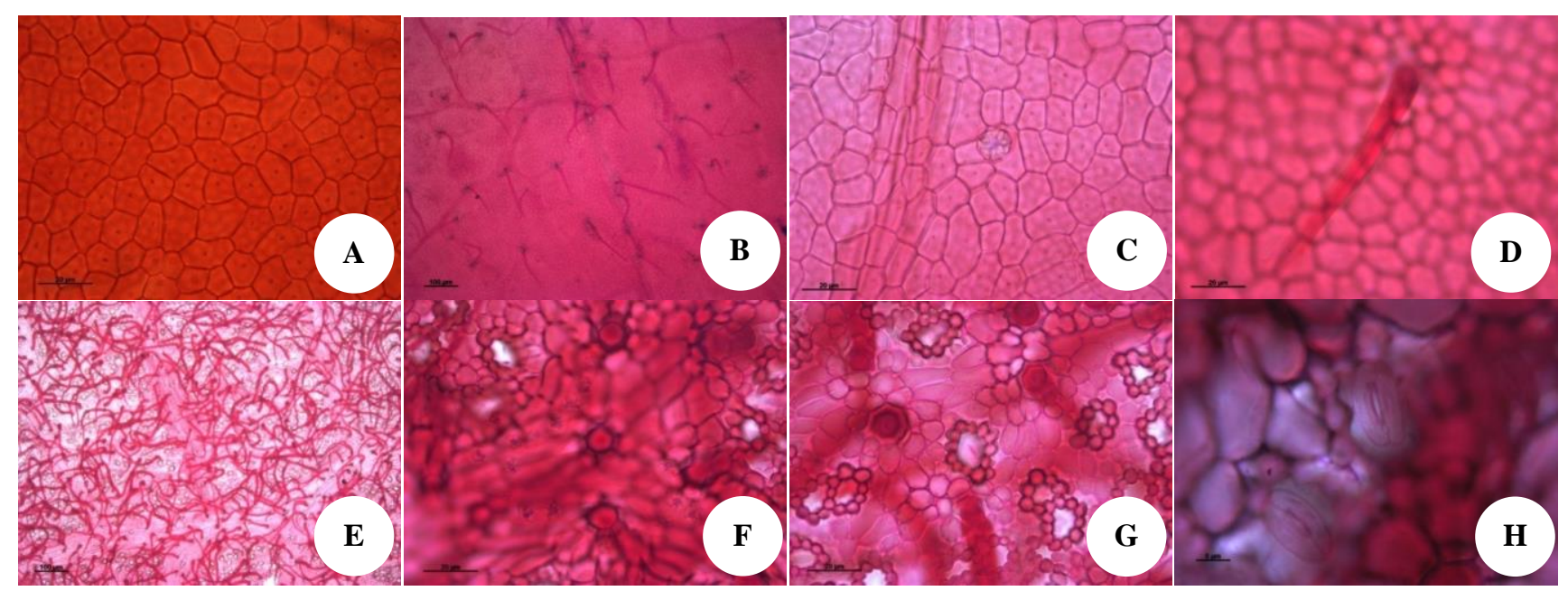

Figure 3. Surface of Enkleia malaccensis. A-D. Upper surface: A. Epidermal cells, B-D. Trichomes, C. Cruse crystal; E-H. Lower surface: E. Epidermal cells and trichomes, F. Druse crystal, G. The stomata complex and bead necklace liked subsidiary cells, H. Stamata

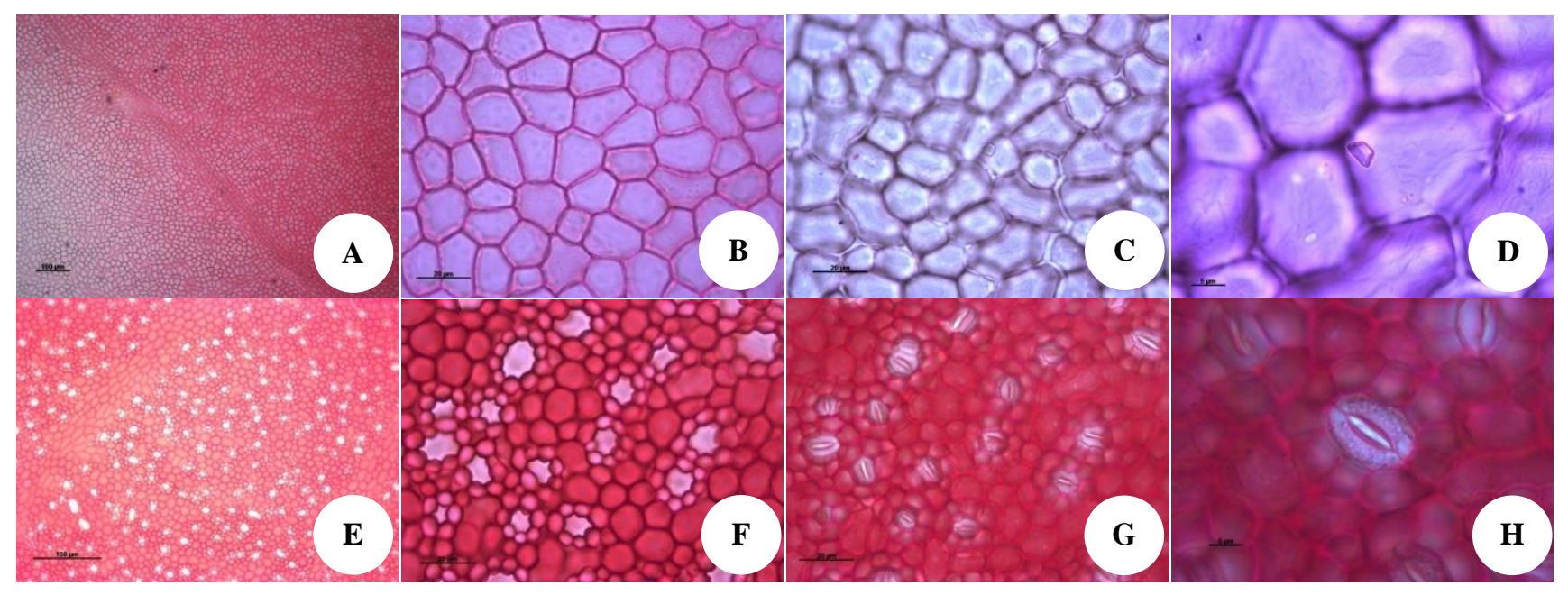

Figure 4. Surface of Enkleia thorelii. A-D. Upper surface: A-B. epidermal cells, C. Cutin ornamentals, D. Cutin ornamental and crystal; E-H. Lower surface: E. Epidermal cells, F. Bead necklace liked subsidiary cells, G-H. The stomata complex and subsidiary cells

Ecology. - deciduous dipterocarp forest, alt. 200-300 m above sea level

Flowering period. - March

Fruiting period. - July

Traditional use. - Medicinal plants (roots, woods, barks, leaves, fruits)

Specimens examined. - M. norsaengsri 4654, 5113, 5131 (QBG!).

Conservation status. - The species is currently known only from few natural populations in Thailand. This species is here proposed as being not evaluated by IUCN criteria (2020). Therefore, we suggest treating this species as Vulnerable (VU) and rare species based on the distribution data of this species.

Note. - Endemic to Thailand, according to IUCN criteria (2020).

\section{Palynology of the genus Enkleia in Thailand}

Pollen of Enkleia malaccensis and E. thorelii were studied under LM and SEM. The descriptions of both species were reported below. This study is the first time reported.

Enkleia malaccensis : spheroidal shape, Medium size, $42.58 \pm 2.21 \mu \mathrm{m}$ in diameter, radial symmetry, exile sculpturing crotonoid pattern (Figures 2A-2C)

Enkleia thorelii : spheroidal shape, Medium size, $46.50 \pm 5.51 \mu \mathrm{m}$ in diameter, radial symmetry, exile sculpturing crotonoid pattern (Figures 2D-2F)

\section{Peeling leaf surfaces of the genus Enkleia in Thailand}

Peeling leaf surfaces of Enkleia malaccensis and E. thorelii were studied under LM. The descriptions of both species were reported below. This study is the first time reported. 
Enkleia malaccensis : The epidermal cells on both surfaces are four to seven-sided. Cutin ornamental is not present on both surfaces. The stomata found only on lower surface. The stomata develop sunk under epidermal cells. The stomatal complexes are anomocytic. Many spheroidal subsidiary cells over the stomata are liked bead necklace. Trichomes are found on both surfaces. Trichomes on lower surfaces are frequent than upper surfaces. The length of trichomes on lower surface is longer than upper surface. Druse crystals are presented on both surfaces. (Fig. 3)

Enkleia thorelii: The epidermal cells on both surfaces are four to five-sided. Cutin ornamental is present on upper surface. The stomata found only on lower surface. The stomata develop sunk under epidermal cells. The stomatal complexes are anomocytic. Many spheroidal subsidiary cells over the stomata are liked bead necklaces. Trichomes are not presented on both surfaces. Crystals are presented on upper surfaces. (Fig. 4)

In conclusion, taxonomic revision of the genus Enkleia is studied. The genus is belonging to subfamily Thymelaeoideae, tribe Daphneae and Linostoma group. Two species are recorded in this study which is Enkleia malaccensis Griff. and E. thorelii (Lecomte) Nevling. The results found that Enkleia siamensis (Kurz) Nevling and $E$. siamensis (Kurz) Nevling subsp. andamanica (Hutch. Ex C. E. Parkinson) Nevling are reduced to Enkleia malaccensis Griff. Therefore both subspecies are recorded as synonym of E. malaccensis. While, E. malaccensis is reported endemic to Thailand. A revise key to species of Enkleia in Thailand is provided. Both species are found in deciduous dipterocarp forest, alt. 200-500 m above sea level. Maha Sarakham province is newly located in $E$. thorelii. The flowering period of both species is found in March. While, the fruiting period is found in July. The fiber from the barks of Enkleia malaccensis can be used as a rope by villagers. Moreover, villagers used the roots, woods, barks, leaves and fruits of E. thorelii as medicinal plants.

Pollens of Enkleia malaccensis and E. thorelii study under LM and SEM are medium size, spheroidal shape, radial symmetry, exile sculpturing crotonoid pattern, differs in diameters $42.58 \pm 2.21 \mu \mathrm{m}$ (E. malaccensis) and $46.50 \pm 5.51 \mu \mathrm{m}$ (E. thorelii). Herber (2002) studied pollen of some species in family Thymelaeaceae except $E$. malaccensis and E. thorelii. It cannot be use classification of genus. Therefore, this study is the first time reported.

Peeling leaf surfaces are studied. The epidermal cells on upper and lower surfaces, stomata complexes, subsidiary cells of E. malaccensis and E. thorelii are presented similar. Trichomes are found only in both surfaces of $E$. malaccensis, while trichomes on both surface of E. thorelii are not presented. The peeling leaf surfaces of Enkleia are studied for the first time. Therefore, trichomes can be used for classification.

\section{ACKNOWLEDGEMENTS}

We would like to thank the Walai Rukhavej Botanical Research Institute and the Laboratory Equipment Center and also the Center of Excellence for Silk Innovation, Division of Research facilitation and dissemination, Mahasarakham University for their facilities during the research. This research was financially supported by Mahasarakham University.

\section{REFERENCES}

Herber BE. 2002. Pollen morphology of the Thymelaeaceae in relation to its taxonomy. Plant Syst Evol 232: 107-121.

IUCN criteria. 2020. The IUCN Red List of Threatened Species.Version 2013.2. http://www.iucnredlist.org/

Kajornjit P, Saensouk S and Saensouk P. 2018. Pollen and anatomy of the genus Globba in Thailand. Science Asia 44 (3): 146-161.

Peterson B. 1997. Thymelaeaceae. In: Santisuk T, Larsen K (eds) Flora of Thailand. Diamond Printing, Bangkok.

Prasawang S, Srinual A. 2020. Comparative leaf and wood anatomical characteristics of Chrysophyllum (Sapotaceae) relate to taxonomy of the species in Thailand. Biodiversitas 21 (4): 1578-1587.

Rakarcha S, Saensouk P and Saensouk S. 2018. Pollen morphology of Dilleniaceae in Thailand. Pak J Bot 50 (4): 1551-1562.

Saensouk P, Theerakulpisut P, Thammathaworn A, Saensouk S, Maknoi C and Kohkaew P. 2015. Pollen Morphology of the Genus Curcuma L. (Zingiberaceae) in the Northeastern Thailand. Science Asia 41: 87-92.

Saensouk S and Saensouk P. 2018. Palynology of family Convolvulaceae in Thailand. Res Knowl 4 (1): 16-33.

The Plant List. $2017 . \quad$ Thymelaeaceae. www.theplantlist.org/browse/A/Dioscoreaceae.

Thammathaworn A. 1995. Handbook for Permanent Slides of Plant Tissues by Paraffin Method. Department of Biology, Faculty of Science, Khon Kaen University, Thailand. 